\title{
IR-783 inhibits breast cancer cell proliferation and migration by inducing mitochondrial fission
}

\author{
PANTONG LI ${ }^{*}$, YU LIU ${ }^{1 *}$, WUYI LIU ${ }^{2},{\text { GUOBING } \mathrm{LI}^{2} \text {, } \text { QIN TANG }^{2} \text {, QIAN ZHANG }}^{2}$, FANING LENG $^{2}$, \\ FANGFANG SHENG ${ }^{2}$, CHANGPENG HU $^{2}$, WENJING LAI ${ }^{2}$, YALI LIU ${ }^{2}$, MIN ZHOU $^{2}$, \\ JINGBIN HUANG ${ }^{2}$, HUYUE ZHOU ${ }^{2}$, RONG ZHANG ${ }^{2}$ and YU ZHAO ${ }^{1}$ \\ ${ }^{1}$ Department of Pharmacy, The University-Town Hospital of Chongqing Medical University, Chongqing 401331; \\ ${ }^{2}$ Department of Pharmacy, Xinqiao Hospital, Army Medical University, Chongqing, 400037, P.R. China
}

Received January 2, 2019; Accepted May 31, 2019

DOI: 10.3892/ijo.2019.4821

\begin{abstract}
IR-783, a near-infrared heptamethine cyanine dye, has been reported to possess cancer targeting and anticancer effects; However, the molecular mechanism by which IR-783 exhibits anti-breast cancer activity is unclear. In the present study, the inhibitory effects of IR-783 on the proliferation and migration of breast cancer cells were investigated. Our results revealed that IR-783 inhibited MDA-MB-231 and MCF-7 cell proliferation in a dose- and time-dependent manner by inducing cell cycle arrest at the G0/G1 phase. In addition, a Transwell assay demonstrated that IR-783 treatment suppressed the migratory ability of MDA-MB-231 and MCF-7 cells. Furthermore, IR-783 treatment decreased the expression levels of matrix metalloproteinase (MMP)-2 and MMP-9 in MDA-MB-231 cells. Furthermore, IR-783 induced MDA-MB-231 and MCF-7 cell mitochondrial fission, and also decreased the levels of ATP. This was accompanied with a decrease in polymerized filamentous actin, which is the fundamental component of filopodia at the cell surface. Collectively, the results of the present study demonstrated that IR-783 inhibited the proliferation and migration of MDA-MB-231 and MCF-7 cells by inducing mitochondrial fission and subsequently decreasing ATP levels, resulting in cell cycle arrest and filopodia formation suppression. These findings suggest that IR-783 may be developed into an effective novel drug for treating breast cancer.
\end{abstract}

Correspondence to: Professor Yu Zhao, Department of Pharmacy, The University-Town Hospital of Chongqing Medical University, 55 University Town Road, Chongqing 401331, P.R. China

E-mail: zhaoyuu@hotmail.com

Professor Rong Zhang, Department of Pharmacy, Xinqiao Hospital, Army Medical University, 83 Xinqiao Road, Chongqing 400037, P.R. China

E-mail: xqpharmacylab@126.com

${ }^{*}$ Contributed equally

Key words: IR-783, breast cancer, proliferation, migration, mitochondrial fission

\section{Introduction}

Breast cancer is a deadly form of cancer and the main cause of cancer-associated mortality among women worldwide (1). Surgical resection, radiotherapy, chemotherapy and molecular-targeted therapy are the main methods of clinical breast cancer treatment (2). At present, improvements in early diagnostic methods and treatment strategies have led to notable decreases in the mortality rate; however, a considerable portion of patients eventually succumb with tumor recurrence and drug resistance $(3,4)$. Therefore, it is crucial to develop novel and alternative therapeutic agents for the treatment of breast cancer.

Near infrared (NIR) has a high potential in the diagnosis and treatment of various diseases, including colorectal cancer, gastric cancer and kidney cancer (5-7), owing to its well-visualized and notable tissue permeability properties (8). Of all types of NIR agents, IR-783 has received increasing attention for its excellent imaging and tumor targeting properties $(9,10)$. Previously, several studies have revealed that IR-783 can be specifically taken up and enriched by cancer cells, targeting tumors of the brain, prostate and colon with low-toxicity for normal tissues (10-12). In recent years, researchers have reported that IR-783 possessed the ability to reduce the viability of cancer cells via $\mathrm{pH}$ switchable photothermal therapy and photodynamic therapy $(13,14)$. In addition, our group previously reported that IR-783 decreased MDA-MB-231 cell viability and promoted mitochondrial apoptosis of human breast cancer cells $(15,16)$.

Mitochondria are important double-membrane cellular organelles, which are essential for cell homeostasis and survival, as well as generating the majority of cellular energy in the form of adenosine triphosphate (ATP) (17-19). Furthermore, mitochondria are dynamic organelles that undergo continuous fission and fusion; the structure and function of which are highly regulated to meet the physiological needs of the cell $(20,21)$. The imbalance of fission and fusion, of mitochondria leads to structural changes and dysfunction of the mitochondria, and serves an important role in cell-cycle progression, apoptosis, mitophagy and ATP production (15,21-23). Importantly, mitochondrial dynamics are essential for cell proliferation, development, death and diseases (24). Additionally, previous 
studies have demonstrated that IR-783 promoted breast cancer cells apoptosis by inducing mitochondrial fission (15). Therefore, we hypothesized that mitochondria may also contribute to IR-783-induced inhibition of breast cancer cell proliferation and migration.

In the present study, we aimed to investigate the inhibitory effects of IR-783 on breast cancer cell proliferation and migration. Our results indicated that IR-783 inhibited MDA-MB-231 and MCF-7 cell proliferation by inducing cell cycle arrest at the G0/G1 phase. Additionally, IR-783 inhibited MDA-MB-231 and MCF-7 cell migration, which was accompanied with inhibiting filopodia formation with reductions in filamentous actin (F-actin) polymerization. Furthermore, mechanistic analysis revealed that IR-783 treatment induced mitochondrial fission through inhibiting the expression of mitochondrial fusion proteins optic atrophy 1 (OPA1), mitofusin 1 (Mfn1) and mitofusin 2 (Mfn2), but promoting that of the fission proteins, mitochondrial fission factor (MFF), mitochondrial fission 1 protein (Fis1) and dynamin-related protein 1 (Drp1). Our data indicated the underlying mechanism of IR-783 on inhibiting breast cancer cell proliferation and migration, and provide a mechanistic basis for the potential application of IR-783 in the treatment of breast cancer.

\section{Materials and methods}

Chemicals and antibodies. The NIR dye IR-783 was obtained from Sigma-Aldrich (Merck KGaA) and dissolved in sterile distilled water as a stock solution. The antibodies used in the present study were as follows: Anti-Cyclin D1 (cat.no. sc-8396), anti-Cyclin E (cat. no. sc-481), anti-cyclin-dependent kinase 2 (CDK2; cat. no. sc-6248), anti-OPA1 (cat. no. sc-393296), anti-Mfn1 (cat. no. sc-1666447), anti-Mfn2 (cat. no. sc-515647), anti-MFF (cat. no. sc-398617), anti-Fis1 (cat.no. sc-376447) and anti-Drp1 (cat. no. sc-271583) were obtained from Santa Cruz Biotechnology, Inc. Anti-matrix metalloproteinase-2 (MMP-2; cat. no. 40994) and anti-MMP-9 (cat. no. 13667) were obtained from Cell Signaling Technology, Inc. Anti-GAPDH (cat. no. AG019-1) was obtained from Beyotime Institute of Biotechnology.

Cell culture. The human breast cancer cell lines MDA-MB-231 and MCF-7 were purchased from the American Type Culture Collection. The cells were cultured in Dulbecco's modified Eagle's medium (DMEM) containing 10\% fetal bovine serum (FBS), all from Gibco (Thermo Fisher Scientific, Inc.). Cells were cultured at $37^{\circ} \mathrm{C}$ with $5 \% \mathrm{CO}_{2}$ and digested every 2 days by $0.25 \%$ trypsin (Gibco; Thermo Fisher Scientific, Inc.).

MTT assay. Cells (2x10 4 cells/well) were seeded onto 96-well plates and allowed to attach. After treatment with various concentrations of IR-783 (0, 20, 40, 60, 80, 100, 120, 140 and $160 \mu \mathrm{M}$ ) for $24 \mathrm{~h}$ or with $80 \mu \mathrm{M}$ IR-783 for different time intervals $(0,3,6,12,24,36,48$ and $72 \mathrm{~h})$ in a $5 \% \mathrm{CO}_{2}$ incubator at $37^{\circ} \mathrm{C}$, cells were incubated with $20 \mu 1 \mathrm{MTT}$ solution ( $5 \mathrm{mg} / \mathrm{ml}$; Sigma-Aldrich; Merck KGaA), cells were treated at $37^{\circ} \mathrm{C}$ for $4 \mathrm{~h}$. Then, the medium was removed slowly and $150 \mu \mathrm{l}$ dimethyl sulfoxide (Eastman Kodak) was added to dissolve the formazan crystals. The proliferation of cells was determined using a microplate reader (Varioskan Flash; Thermo Fisher Scientific, Inc.) at $490 \mathrm{~nm}$. All results were repeated in three independent experiments.

Clone formation assay. Cells were digested by $0.25 \%$ trypsin and seeded in a $5-\mathrm{cm}$ sterile petri-dish at a density of 100 cells per dish overnight. Then, cells were treated with different concentrations of IR-783 $(0,80$ and $160 \mu \mathrm{M})$ the next day and incubated at $37^{\circ} \mathrm{C}$. After $24 \mathrm{~h}$, the supernatant was discarded carefully and fresh DMEM with $10 \%$ FBS was added. Cells were cultured for 2-3 weeks until clones were visible. After removing culture medium, clones were washed for three times with PBS, fixed with $4 \%$ paraformaldehyde for $15 \mathrm{~min}$, then stained with $0.1 \%$ crystal violet for $10 \mathrm{~min}$ at room temperature. Clones were counted using Photoshop CS6 software (version 13.0; Adobe Systems, Inc.). All results were performed for three independent times.

5'-Ethynyl-2'-deoxyuridine (EdU) assay. Cell proliferation was assessed with a BeyoClick ${ }^{\mathrm{TM}}$ EDU-488 imaging Kit (cat. no. C0071S; Beyotime Institute of Biotechnology). Cells were inoculated onto slides of 24-well plates at a density of $1 \times 10^{4}$ cells/well and incubated overnight at $37^{\circ} \mathrm{C}$. Then, IR-783 $(0,80$ and $160 \mu \mathrm{M})$ was added to cells and cultured for $24 \mathrm{~h}$. Subsequently, cells were exposed to $20 \mu \mathrm{M}$ EdU for $2 \mathrm{~h}$ at $37^{\circ} \mathrm{C}$. Cells were then fixed with $4 \%$ paraformaldehyde for $15 \mathrm{~min}$, followed by the addition of $200 \mu 10.5 \%$ Triton X-100 (AppliChem $\mathrm{GmbH}$ ) for $10 \mathrm{~min}$ to increase cell permeability at room temperature. After washing with PBS for three times, $200 \mu \mathrm{l}$ of click reaction solution was added according to the instructions and cells were incubated for another $30 \mathrm{~min}$ at room temperature in the dark. Next, cells were washed again and stained with $100 \mu \mathrm{l}$ of Hoechst 33342 for $30 \mathrm{~min}$ at room temperature. The samples were analyzed and imaged with a fluorescence microscope (BX63; Olympus Corporation) at x20 magnification. EdU-positive cells were analyzed in three randomly selected field by using Photoshop CS6 software (version 13.0; Adobe Systems, Inc.).

Cell cycle analysis. Cell cycle analysis was performed by flow cytometry. Cells were seeded in a 6-well plate at a density of $1 \times 106$ cells/well and cultured overnight. IR-783 (0, 80 and $160 \mu \mathrm{M}$ ) was added and incubated for $24 \mathrm{~h}$. Cells were collected and washed twice with cold PBS, then fixed in cold $75 \%$ ethanol at $4^{\circ} \mathrm{C}$ overnight. Subsequently, the cells were washed with cold PBS and incubated with $50 \mu \mathrm{g} / \mathrm{ml}$ RNase and $100 \mu \mathrm{g} / \mathrm{ml}$ propidium iodide (cat. no. 556547; BD Biosciences) for $30 \mathrm{~min}$ at $37^{\circ} \mathrm{C}$ in the dark. The samples were analyzed with a flow cytometer (FACScan) using CellQuest software (version 5.1) (both from BD Biosciences).

Wound healing assay. The migration ability of MDA-MB-231 cells was assessed using a wound healing assay. Cells $\left(5 \times 10^{5}\right.$ cells/well) were cultured in 6-well plates and allowed to grow to $80-90 \%$ confluence. Scratches of a predetermined length were created with a $200 \mu$ l pipette tip. After washing the scratched cells with PBS, IR-783 (0,80 and $160 \mu \mathrm{M})$ were added and incubated for 24 or $48 \mathrm{~h}$ at $37^{\circ} \mathrm{C}$. The images of wounds were imaged using a Cell Imaging System (Carl Zeiss AG). The wound width was measured using ImageJ software 
(version 1.52a; National Institute of Health); wound healing rate $(\%)=100 \% \times(0 \mathrm{~h}$ width-24/48 $\mathrm{h}$ width $) / 0 \mathrm{~h}$ width.

Transwell assay. Cells $\left(2 \times 10^{4}\right.$ cells/well) were plated in the upper chamber of a Transwell chamber with $200 \mu$ l serum-free DMEM, while $600 \mu \mathrm{l}$ media containing 30\% FBS (Gibco; Thermo Fisher Scientific, Inc.) was added in the lower chamber. IR-783 $(0,80$ and $160 \mu \mathrm{M})$ was applied to both chambers. After $24 \mathrm{~h}$ of treatment in a $37^{\circ} \mathrm{C}$ incubator, non-invasive cells on the upper surface of the membrane were gently wiped away with a cotton swab, while the invasive cells on the low surface of the membrane were fixed with $4 \%$ paraformaldehyde for $15 \mathrm{~min}$ and stained with $0.1 \%$ crystal violet for $10 \mathrm{~min}$ at room temperature. Three independent fields in each well were imaged under a light microscope (DP26; Olympus Corporation) at $\mathrm{x} 20$ magnification, and the number of cells in each field was counted.

ATP luminescence assay. The cellular ATP levels were measured with an ATP Assay Kit (cat. no. S0026; Beyotime Institute of Biotechnology). A standard curve of ATP concentration $(0.01,0.03,0.1,0.3,1.0,3.0,10 \mu \mathrm{M})$ was created from a known amount of ATP and then used to determine the ATP content of the samples. Briefly, after exposure to different concentrations of IR-783 $(0,40,80,120$ and $160 \mu \mathrm{M})$ for $24 \mathrm{~h}$, cells were harvested and washed twice with PBS. Then, cells were lysed and centrifuged at $12,000 \mathrm{x}$ g for $10 \mathrm{~min}$ at $4^{\circ} \mathrm{C}$, and the supernatant was collected and mixed with $100 \mu \mathrm{l}$ ATP detection working solution. The luminescence values were determined using a microplate reader at $420 \mathrm{~nm}$ (Varioskan Flash; Thermo Fisher Scientific, Inc.). The levels of ATP were expressed as a percentage of the control, which was set at $100 \%$.

Transmission electron microscopy. For electron microscopy, after $24 \mathrm{~h}$ incubation with $80 \mu \mathrm{M}$ IR-783, MDA-MB-231 cells were collected and washed twice with PBS, and fixed in fresh $2.5 \%$ glutaraldehyde at $4^{\circ} \mathrm{C}$ overnight. Samples were fixed for $2 \mathrm{~h}$ in $2 \%$ osmium tetroxide at $4^{\circ} \mathrm{C}$, dehydrated using a graded series of ethanol and embedded in Epon. Then, sections $(70 \mathrm{~nm})$ were made using an ultra-Microtome (Leica EM UC7; Leica Microsystems, Inc.), stained with 3\% uranyl acetate and $3 \%$ lead citrate for $15 \mathrm{~min}$ at room temperature. The morphology of mitochondria was studied using a Tecnai 10 transmission electron microscope (Philips Healthcare).

Fluorescence microscopy. Cells were inoculated into 24-well plates with coverslips overnight. After treatment with $80 \mu \mathrm{M}$ IR-783, cells were stained with $100 \mathrm{nM}$ MitoTracker Red CMXRos (Beyotime Institute of Biotechnology) for $30 \mathrm{~min}$ at $37^{\circ} \mathrm{C}$ in the dark, then washed three times with culture medium for 5 min each time. Subsequently, cells were fixed with $4 \%$ paraformaldehyde for $10 \mathrm{~min}$ at room temperature, washed with PBS for three times, and observed using a laser-scanning confocal microscope (LSM780NLO; Carl Zeiss AG) at x63 magnification, the representative images were randomly selected from five fields of view. For staining of the actin cytoskeleton, cells were treated with $80 \mu \mathrm{M}$ IR-783 for $24 \mathrm{~h}$ at $37^{\circ} \mathrm{C}$, then cells were fixed with $4 \%$ paraformaldehyde for $15 \mathrm{~min}$ and permeabilized with $0.1 \%$ Triton X-100 for $5 \mathrm{~min}$ at room temperature. F-actin was incubated with Alexa Fluor ${ }^{\circledR} 488$ Phalloidin (CST, 8878S) for $30 \mathrm{~min}$ at $37^{\circ} \mathrm{C}$ in the dark; cells were counterstained with DAPI for 5 min at room temperature (cat. no. C1002; Beyotime Institute of Biotechnology). Cell images were collected using a laser-scanning confocal microscope (LSM780NLO; Carl Zeiss AG) at x63 magnification, the representative images were randomly selected from five fields of view.

Western blotting. MDA-MB-231 cells $\left(1 \times 10^{6}\right.$ cells $\left./ \mathrm{ml}\right)$ were treated with IR-783 for $24 \mathrm{~h}$, then harvested and lysed in cell lysis solution (cat. no. P0013; Beyotime Institute of Biotechnology) with PMSF. A BCA protein assay kit (cat. no. P0010, Beyotime Institute of Biotechnology) was used to quantify protein concentration. Proteins were quantified via a BCA assay. The proteins lysate samples $(15,30$ or $60 \mu \mathrm{g})$ were separated via 10-12\% SDS-PAGE and then transferred to polyvinylidene difluoride membranes (EMD Millipore). The membranes were blocked with 5\% skim milk for $2 \mathrm{~h}$ at room temperature and incubated with specific primary antibodies overnight at $4^{\circ} \mathrm{C}$. The following antibodies were used: Anti-Cyclin D1 (diluted 1:500), anti-Cyclin E (diluted 1:500), anti-CDK2 (diluted 1:500), anti-OPA1 (diluted 1:500), anti-Mfn1 (diluted 1:500), anti-Mfn2 (diluted 1:500), anti-MFF (diluted 1:500), anti-Fis1 (diluted 1:500), anti-Drp1 (diluted 1:500), anti-MMP-2 (diluted 1:1000), anti-MMP-9 (diluted 1:1,000) and anti-GAPDH (diluted 1:2,000). Membranes were washed three times with TBST and then incubated with anti-rabbit (diluted 1:50,000, cat. no. 150204) or anti-mouse (diluted 1:50,000, cat, no. 130639) horseradish peroxidase secondary antibodies (Kirkegaard \& Perry Laboratories Inc.) for $2 \mathrm{~h}$ at room temperature. The immunoreactive bands were visualized using an enhanced chemiluminescence kit (Amersham ECL or ECL Plus; GE Healthcare Life Sciences); protein expression was quantified using Quantity One software (version 4.6; Bio-Rad Laboratories, Inc.).

Statistical analysis. All data were presented as the mean \pm standard deviation using GraphPad prism 6.0 software (GraphPad Software, Inc.). Statistical analysis between different groups were determined using one-way analysis of variance with a Dunnett's or Tukey's post-hoc test. $\mathrm{P}<0.05$ was considered to indicate a statistically significant difference.

\section{Results}

IR-783 suppresses MDA-MB-231 and MCF-7 cell proliferation. The chemical structure of IR-783 is presented in Fig. 1A. First, we evaluated the inhibitory effects of IR-783 on MDA-MB-231 and MCF-7 cells using an MTT assay. As shown in Fig. 1B and C, we reported that IR-783 treatment significantly decreased cell proliferation in a dose- and time-dependent manner compared with the control. To further confirm the effects of IR-783 on cell proliferation, a colony formation assay was performed. As presented in Fig. 1D, our results indicated that the number of colonies formed in IR-783-treated group was significantly reduced in MDA-MB-231 and MCF-7 breast cancer cells compared with the control. Furthermore, the effects of IR-783 on cell proliferation in MDA-MB-231 and MCF-7 cells was examined with an EdU assay. The results revealed significant fewer EdU-positive cells following treatment with IR-783 
<smiles>CC1(C)C(=CC=C2CCCC(C=CC3=[N+](CCC(=O)O)c4ccccc4C3(C)C)=C2Cl)N(CCC(N)=O)c2ccccc21</smiles>

IR-783

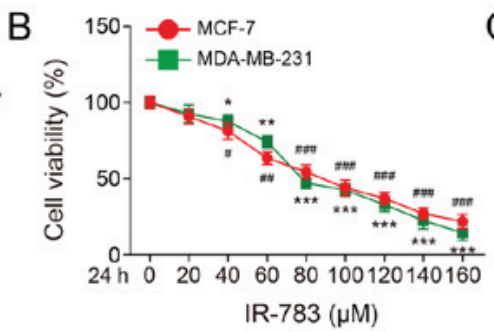

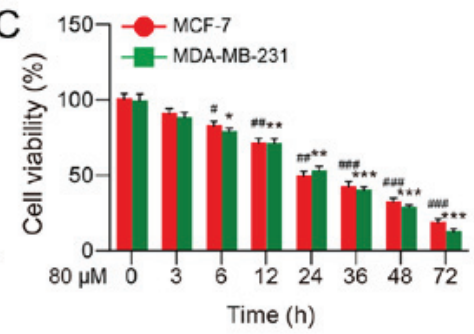
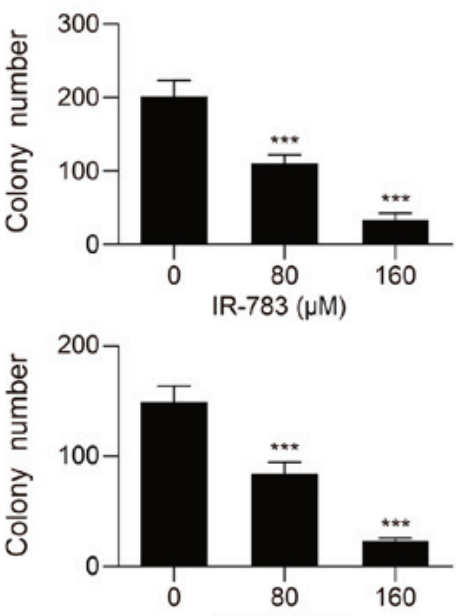

IR-783 ( $\mu \mathrm{M})$

E
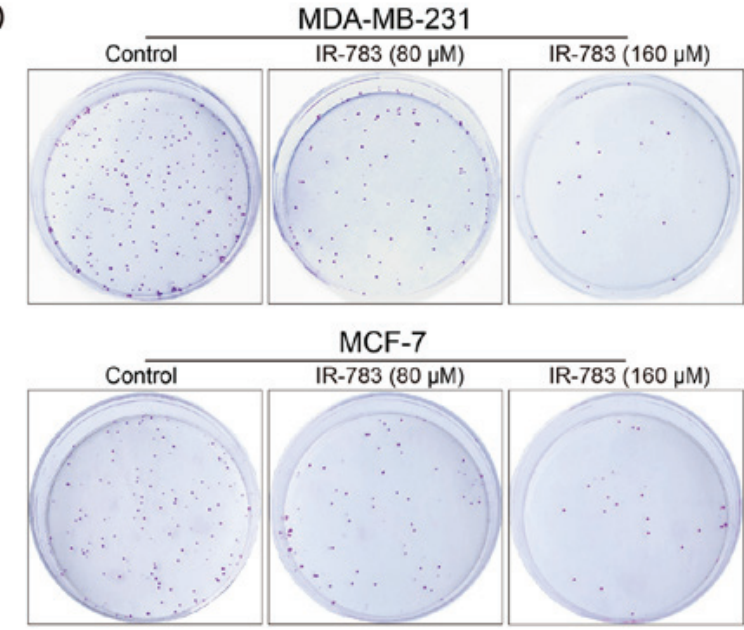

MCF-7
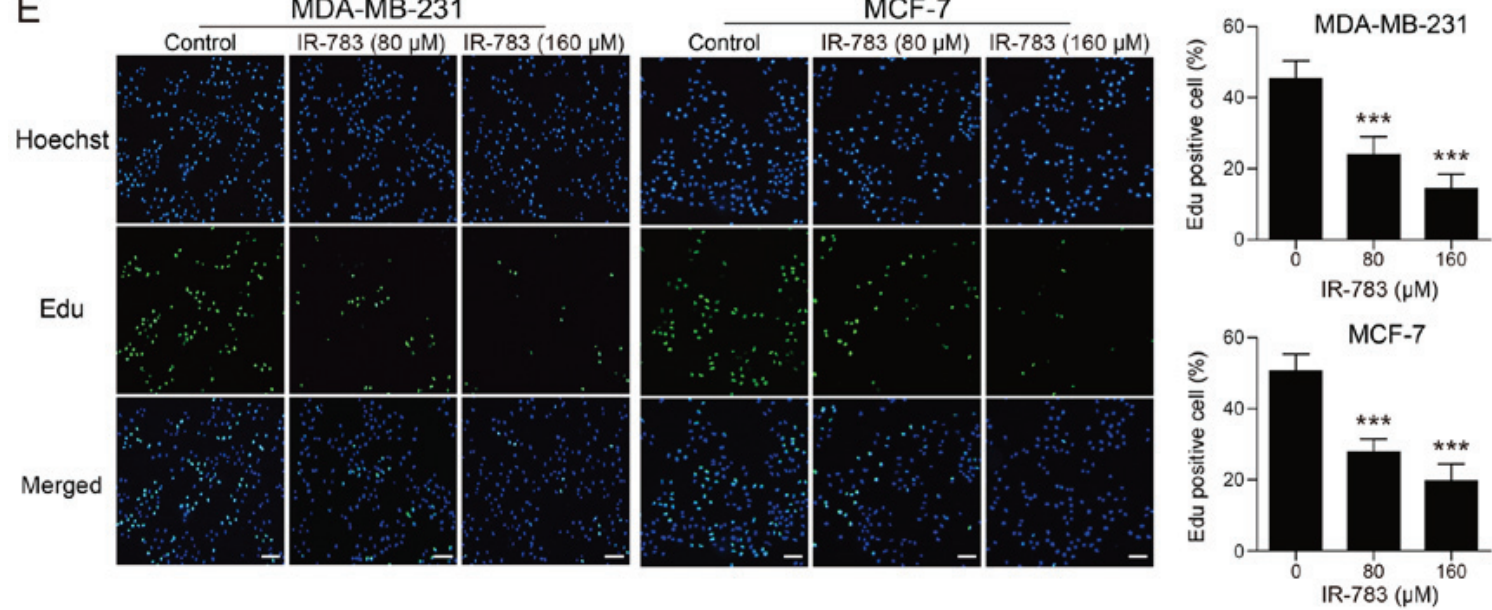

Figure 1. IR-783 suppresses MDA-MB-231 and MCF-7 cell proliferation. (A) Chemical structure of IR-783. (B and C) MDA-MB-231 and MCF-7 cell proliferation as determined by an MTT assay; cells were treated with different concentrations of IR-783 $(0,20,40,60,80,100,120,140$ and $160 \mu \mathrm{M})$ for $24 \mathrm{~h}$ or with $80 \mu \mathrm{M}$ IR-783 for different time intervals $(0,3,6,12,24,36,48$ and $72 \mathrm{~h})$. All data are expressed as the mean \pm standard error of the mean, from three independent experiments. ${ }^{\#} \mathrm{P}<0.05,{ }^{\# \#} \mathrm{P}<0.01,{ }^{\# \# "} \mathrm{P}<0.001$ vs. the MCF-7 control group, ${ }^{*} \mathrm{P}<0.05,{ }^{* *} \mathrm{P}<0.01,{ }^{* * *} \mathrm{P}<0.001$ vs. the MDA-MB-231 control group. (D) In the colony formation assay, MDA-MB-231 and MCF-7 cells were treated with IR-783 (0, 80 and $160 \mu \mathrm{M})$ for $24 \mathrm{~h}$, then fixed and stained with crystal violet after cultured for 2-3 weeks. All data are expressed as the mean \pm standard error of the mean, from three independent experiments. ${ }^{* * *} \mathrm{P}<0.001$ vs. the control group. (E) MDA-MB-231 and MCF-7 cells were treated with various concentrations of IR-783 (0,80 and $160 \mu \mathrm{M})$ for $24 \mathrm{~h}$. An EdU staining assay was performed to determine the effects of IR-783 on the proliferation of MDA-MB-231 and MCF-7 cells. ${ }^{* * * *} \mathrm{P}<0.001$ vs. the control group. Scale bar, $200 \mu \mathrm{m}$. All data are expressed as the mean \pm standard error of the mean, from three independent experiments.

compared with the control (Fig. 1E). Taken together, these findings demonstrated that IR-783 suppresses MDA-MB-231 and MCF-7 cell proliferation.

IR-783 induces MDA-MB-231 and MCF-7 cell cycle arrest at the $G 0 / G 1$ phase. To further determine the underlying mechanisms of IR-783-induced inhibition of the growth of MDA-MB-231 and MCF-7 cells, we examined the effects of IR-783 on MDA-MB-231 and MCF-7 cell cycle distribution. After treatment with IR-783 $(0,80$ and $160 \mu \mathrm{M})$ for $24 \mathrm{~h}$, the proportion of MCF-7 cells in G0/G1 phase significantly increased from $34.57 \%$ (without IR-783 treatment) to $57.45 \%$ (cells treated with $160 \mu \mathrm{M}$ IR-783); the proportion of MDA-MB-231 cells in G0/G1 phase significantly increased from $37.04 \%$ (without IR-783 treatment) to $58.26 \%$ (cells treated with $160 \mu \mathrm{M}$ IR -783) (Fig. 2A). No significant differences in the number of cells in $\mathrm{S}$ and $\mathrm{G} 2 / \mathrm{M}$ phase were observed following treatment with IR-783. These results suggested that IR-783 induced MDA-MB-231 and MCF-7 cell cycle arrest at the G0/G1 phase. Furthermore, we detected alterations in the expression of G0/G1 phase-related proteins Cyclin D1, Cyclin E and CDK2 of MDA-MB-231 cells using western 
A
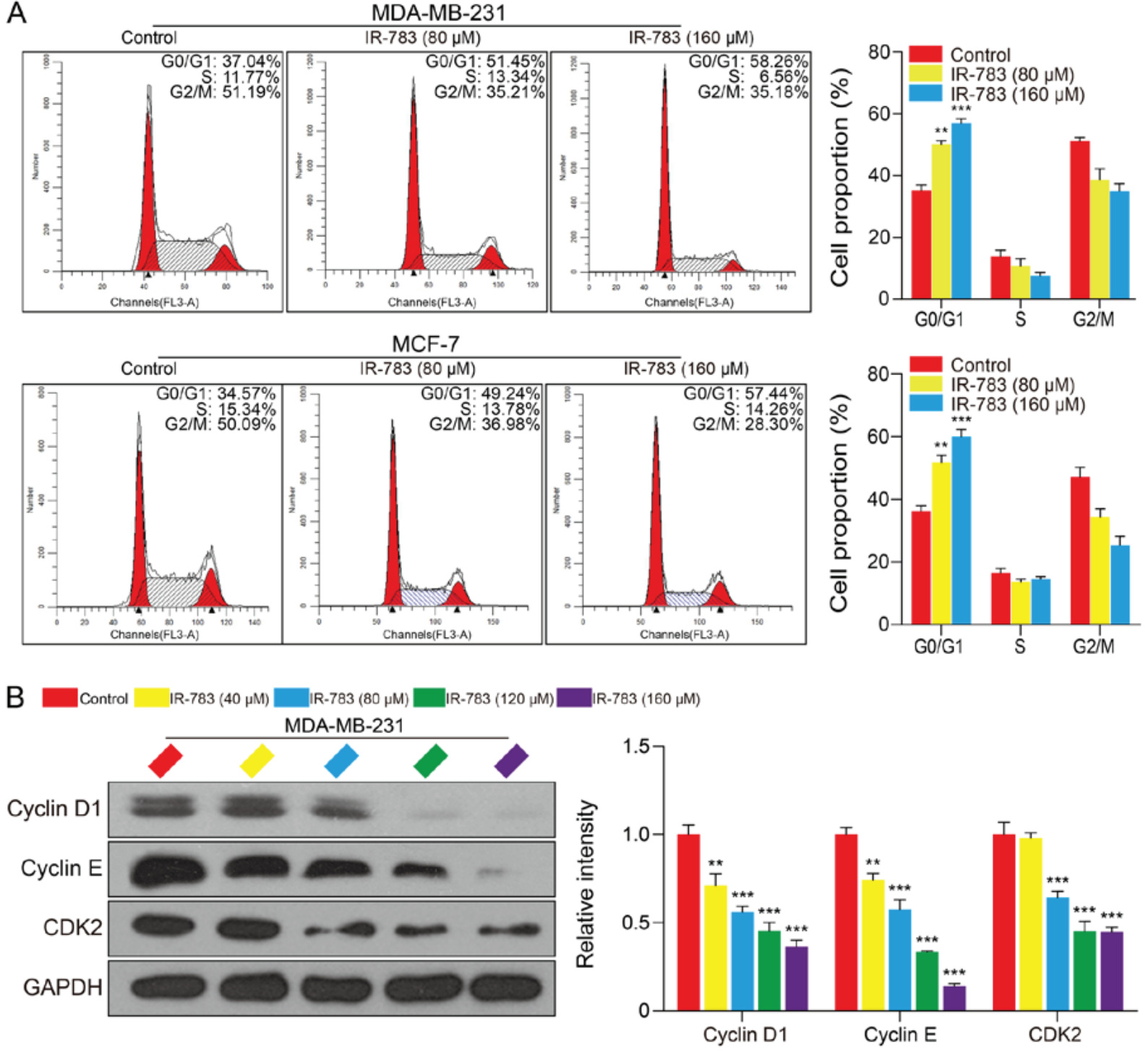

Figure 2. IR-783 induces MDA-MB-231 and MCF-7 cell cycle arrest at G0/G1 phase. (A) MDA-MB-231 and MCF-7 cells were collected after treatment with IR-783 $(0,80$ and $160 \mu \mathrm{M})$ for $24 \mathrm{~h}$ and analyzed by flow cytometry. The distribution (\%) of G0/G1, S and G2/M phases was measured by ModFit LT 5.0 software. (B) The expression levels of G0/G1 phase regulators Cyclin D1, Cyclin E and CDK2 of MDA-MB-231 cell were detected by western blotting. Quantity One software was used to quantify the relative expression of the detected proteins; GAPDH was used as loading control. All data are expressed as the mean \pm standard deviation. $(\mathrm{n}=3){ }^{* * *} \mathrm{P}<0.01,{ }^{* * * *} \mathrm{P}<0.001$ vs. the control group. CDK2, cyclin-dependent kinase 2 .

blotting. The results demonstrated that IR-783 significantly reduced the expression of Cyclin D1, Cyclin E and CDK2 compared with the control (Fig. 2B). These results suggested that IR-783 induces cell cycle arrest at G0/G1 phase.

IR-783 inhibits MDA-MB-231 and MCF-7 cell migration. In addition, a Transwell assay was conducted to examine the effects of IR-783 on MDA-MB-231 and MCF-7 cell migration; a wound healing assay was performed to determine the effects of IR-783 on MDA-MB-231 cell migration. The Transwell assay revealed that IR-783 significantly inhibited the migration of MDA-MB-231 and MCF-7 cells compared with the control (Fig. 3A). Furthermore, the wound healing assay indicated that IR-783 significantly decreased the migration of MDA-MB-231 cells in a dose- and time-dependent manner (Fig. 3B). MMPs, especially MMP-2 and MMP-9, have been reported to be critical regulators involved tumor migration (25). Thus, western blotting was conducted to investigate whether IR-783 affected the expression of MMP-2 and MMP-9 in MDA-MB-231 cells. The western blot assay demonstrated that IR-783 treatment significantly decreased the expression of MMP-2 and MMP-9 in a concentration-dependent manner compared with the control group (Fig. 3C). Collectively, these results indicated that IR-783 inhibits MDA-MB-231 and MCF-7 cell migration.

IR-783 inhibits filopodia formation by reducing $F$-actin formation. Filopodia are critical actin cytoskeletal protrusion structures, and are key factors involved in tumor metastasis (26). Metastatic tumor cells contain numerous filopodia, and the numbers of filopodia are correlated with the invasiveness and migration (27). F-actin is the fundamental component of the cytoskeleton that supports the structure of filopodia, stabilizing them in migrating cancer cells, and it is involved infilopodium formation via the polymerization of actin into bundles under the cell membrane (28). The present study 
A
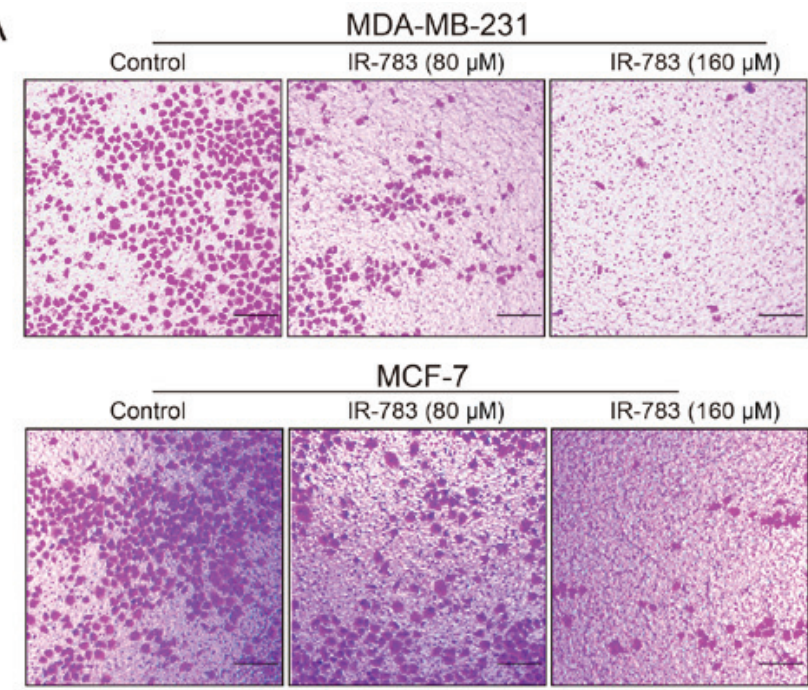

B

$\mathrm{Oh}$

Control IR-783 $(80 \mu \mathrm{M}) \quad$ IR-783 $(160 \mu \mathrm{M})$

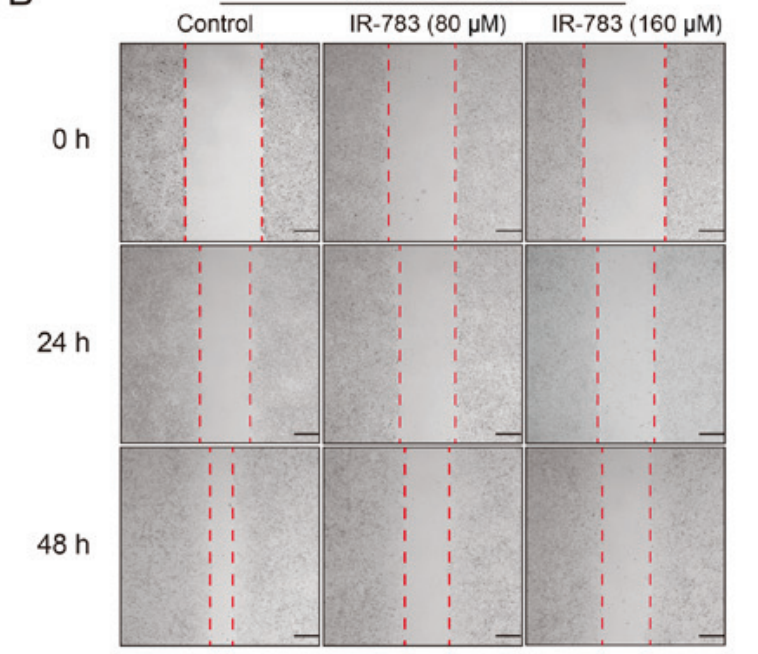

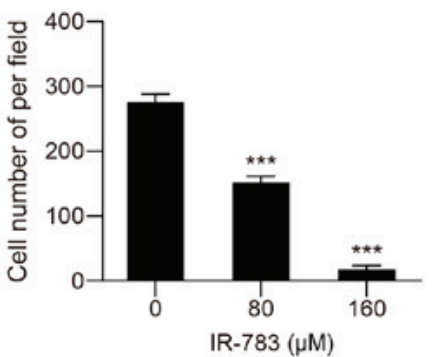

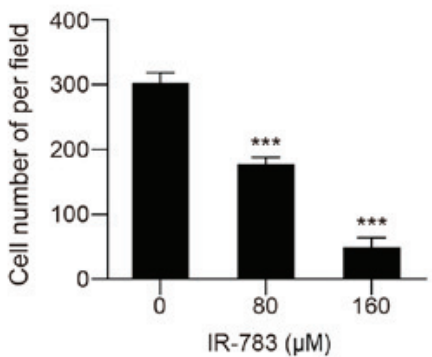

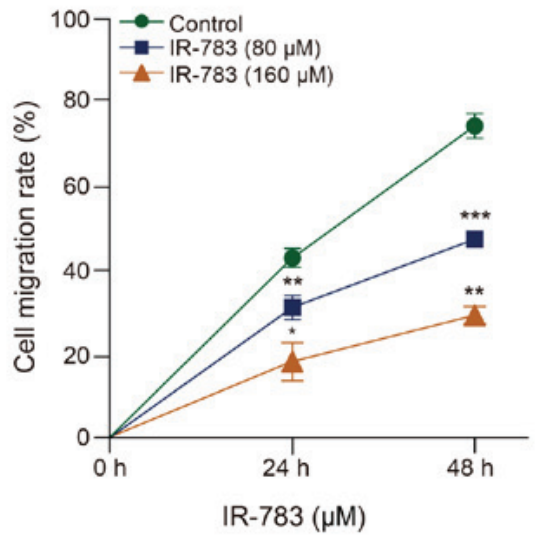

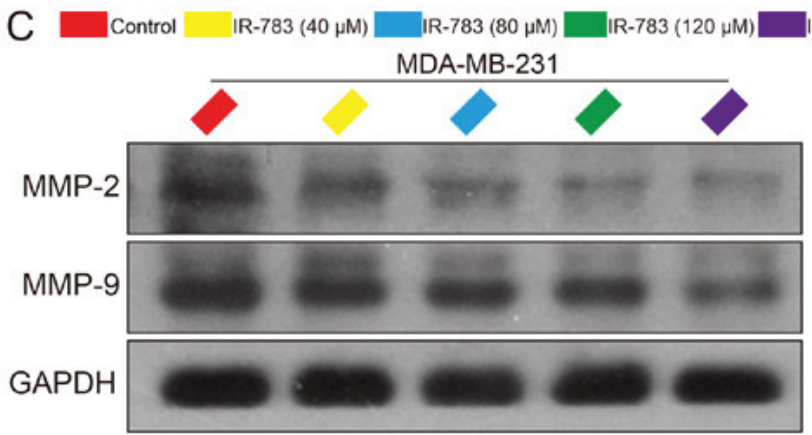

R-783 $(160 \mu \mathrm{M})$

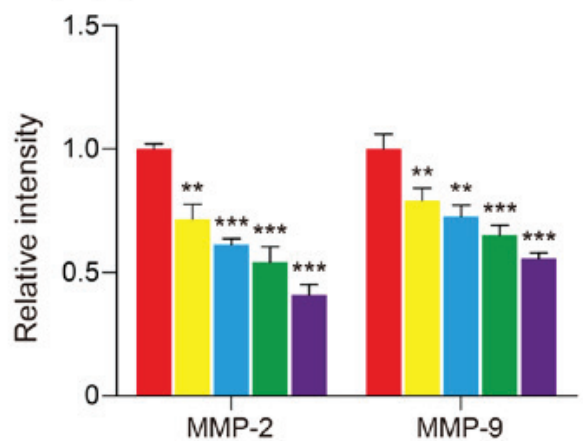

Figure 3. IR-783 inhibits MDA-MB-231 and MCF-7 cell migration. (A) Cells were exposed to various concentrations of IR-783 (0, 80 and $160 \mu \mathrm{M})$ for $24 \mathrm{~h}$. The effects of IR-783 on MDA-MB-231 and MCF-7 cell migration were analyzed using a Transwell assay. Scale bar, $200 \mu \mathrm{m}$. ${ }^{* * * *} \mathrm{P}<0.001 \mathrm{vs}$. the control group. (B) Cells were seeded onto a 6-well plate and treated with different concentrations of IR-783 (0,80 and $160 \mu \mathrm{M})$ for 24 or $48 \mathrm{~h}$. The effects of IR-783 on MDA-MB-231 cell migration were analyzed by a wound healing assay. Scale bar, $100 \mu \mathrm{m} .{ }^{*} \mathrm{P}<0.05,{ }^{* * *} \mathrm{P}<0.01,{ }^{* * * *} \mathrm{P}<0.001$ vs. 0 h. (C) After treatment with IR-783 $(0,40,80,120$ and $160 \mu \mathrm{M})$ for $24 \mathrm{~h}$, western blotting was conducted to analyze the expression of the migration-associated proteins MMP-2 and MMP-9 in MDA-MB-231 cell. Quantity One software was used to analyze the relative quantification of detected proteins; GAPDH was employed as loading control. All data are expressed as the mean \pm standard deviation. $(n=3) .{ }^{* *} \mathrm{P}<0.01,{ }^{* * * *} \mathrm{P}<0.001$ vs. the control group. MMP, matrix metalloproteinase.

reported that the control cell group exhibited a large number of F-actin filaments in the marginal zone and cytoplasm. Incubation with IR-783 induced MDA-MB-231 and MCF-7 cell shrinkage and a marked decrease in the abundance of F-actin (Fig. 4). Collectively, these data suggested that IR-783 inhibits filopodia formation by reducing F-actin formation.
IR-783 induces ATP depletion and mitochondrial fission in $M D A-M B-231$ and MCF-7 cells. ATP, which provides energy for cells, serves an important role in cell life and is central to the fate of cancer cells (29). It has been reported that cancer cells have higher ATP levels than normal cells, and decreases in ATP levels of cancer cells indicates alterations in cancer 


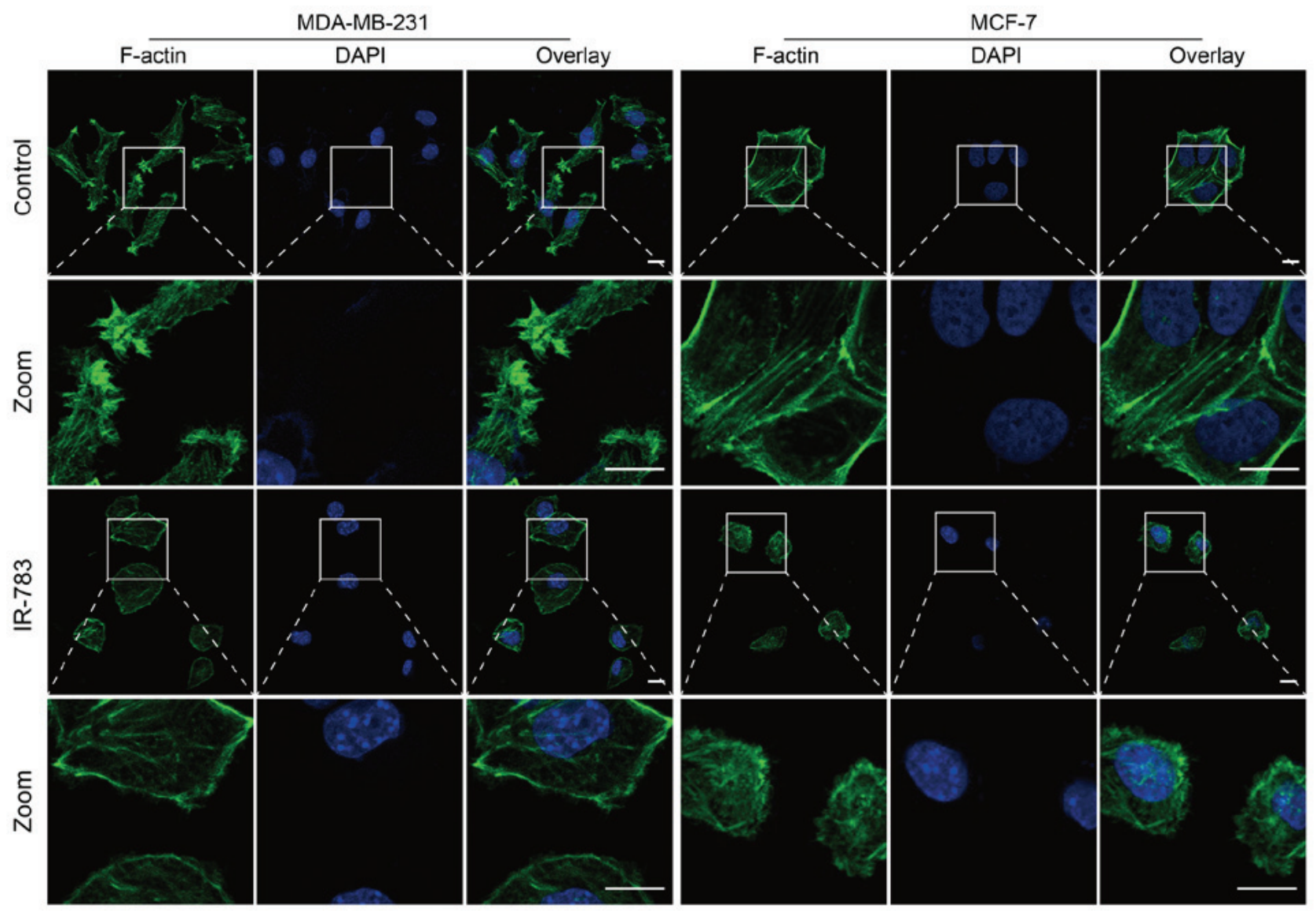

Figure 4. IR-783 inhibits filopodia formation by reducing F-actin formation. (A) Exposure of MDA-MB-231 and MCF-7 cells to $80 \mu \mathrm{M}$ IR-783 for 24 h, the levels of F-actin (green) in cells were labeled and nuclei were stained with DAPI prior to imaging via confocal microscopy. Scale bar, $10 \mu \mathrm{m}$.

cell viability (30). As presented in Fig. 5A, the MDA-MB-231 and MCF-7 cellular ATP levels decreased in a dose-dependent manner in response to the IR-783. Mitochondria are the main organelle in cells involved in the synthesis of ATP. ATP depletion has been reported as an indicator of mitochondrial dysfunction (30). Our transmission electron microscopy results showed that mitochondria of MDA-MB-231 cells swelled; the cristae of mitochondria disintegrated partly as demonstrated by the transparent electronic density area in IR-783 treated cells. On the contrary, the mitochondria presented a slender flat structure in control cells, suggesting that IR-783 induced mitochondrial injury in MDA-MB-231 cells (Fig. 5B). The morphology of mitochondria is dynamically controlled by fission and fusion (20). When alterations in mitochondrial morphology occurred, the balance between fission and fusion is disrupted (20). Next, MDA-MB-231 and MCF-7 cells were stained with MitoTracker Red CMXRos to assess the influence of IR-783 on mitochondrial dynamics. Confocal laser scanning microscopy results revealed that IR-783 treatment promoted mitochondrial fission, as observed by a marked increase in number of small, punctate mitochondria in IR-783 treated cells compared with control cells, which exhibited stable and elongated structures (Fig. 5C). To further confirm these results, western blotting was used to evaluate the expression of mitochondrial fusion regulators OPA1, Mfn1 and Mfn2, and the expression of mitochondrial fission regulators MFF, Fis1 and Drp1 which affect mitochondrial dynamics at the outer mitochondrial membrane. We found that exposure of MDA-MB-231 cells to IR-783 resulted in a significant decrease in the expression of OPA1, Mfn1 and Mfn2, and increased the levels of MFF, Fis1 and Drp1 compared with the control (Fig. 5D and E). These results suggested that IR-783 induces mitochondrial fission and subsequent ATP depletion in MDA-MB-231 and MCF-7 cells.

\section{Discussion}

In recent years, NIR imaging has received increasing attention in the diagnosis and treatment of cancer. IR-783 is a promising imaging NIR dye, and it possesses anti- cancer activity, specific towards prostate, bladder and breast cancers $(31,32)$. IR-783 was determined to induce breast cancer cell apoptosis in vitro and in vivo (15); however, the effects of IR-783 on breast cancer cell proliferation and migration requires further investigation. In the present study, we found that IR-783 significantly suppressed the proliferation and migration of MDA-MB-231 and MCF-7 cells through inhibition of cell cycle progression and filopodia formation.

Cancer cells have greater proliferation ability compared with normal cells. Proliferation of cancer cells is the essential steps of tumor incidence and development (33). In the present study, IR-783 treatment effectively inhibited the proliferation and colony formation ability of MDA-MB-231 and MCF-7 cells. Additionally, IR-783 was reported to induce cell cycle arrest at the G0/G1 phase in a dose-dependent manner in the present study. The cell cycle is a physiological process comprising G0/G1, S 

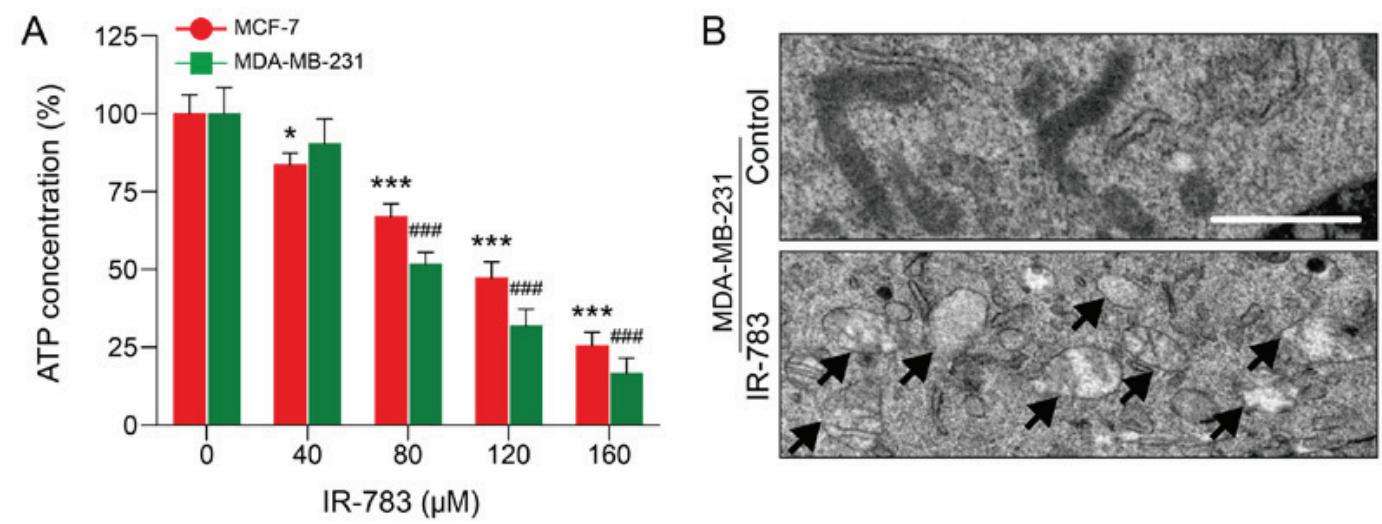

C
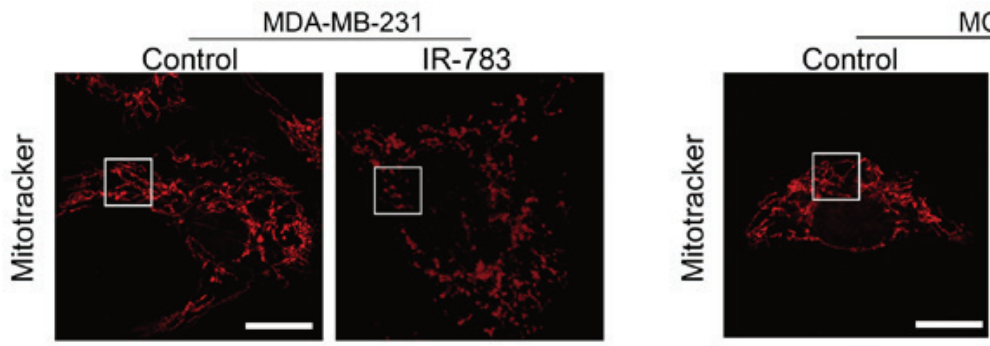

MCF-7
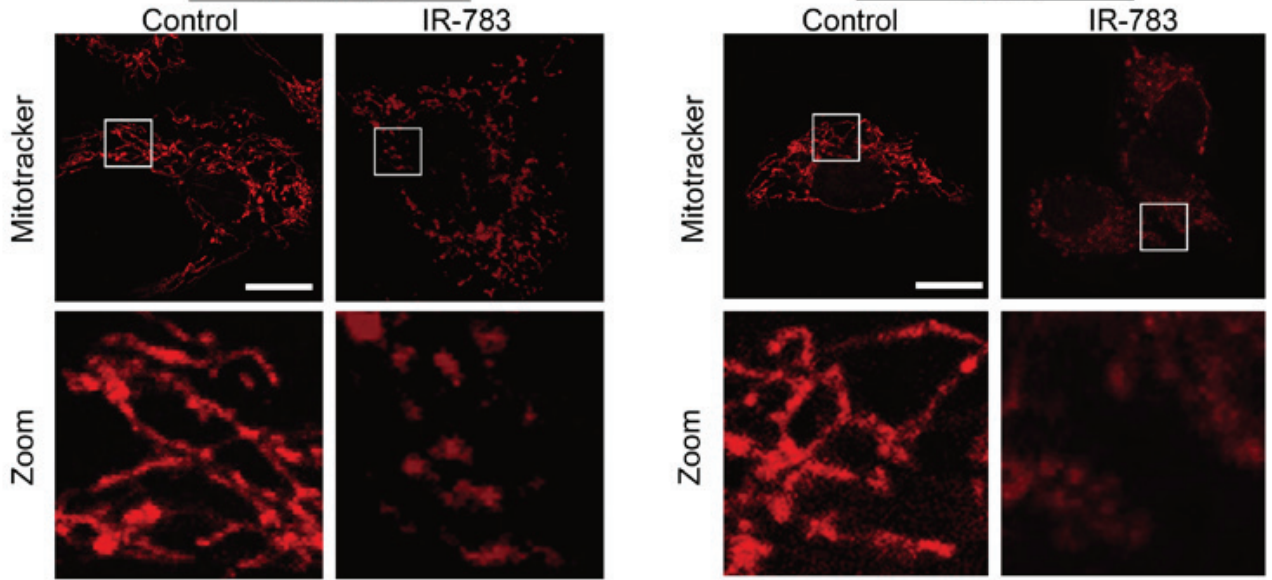

$\mathrm{D}$

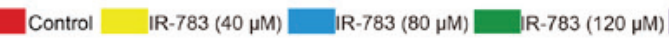

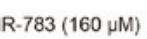
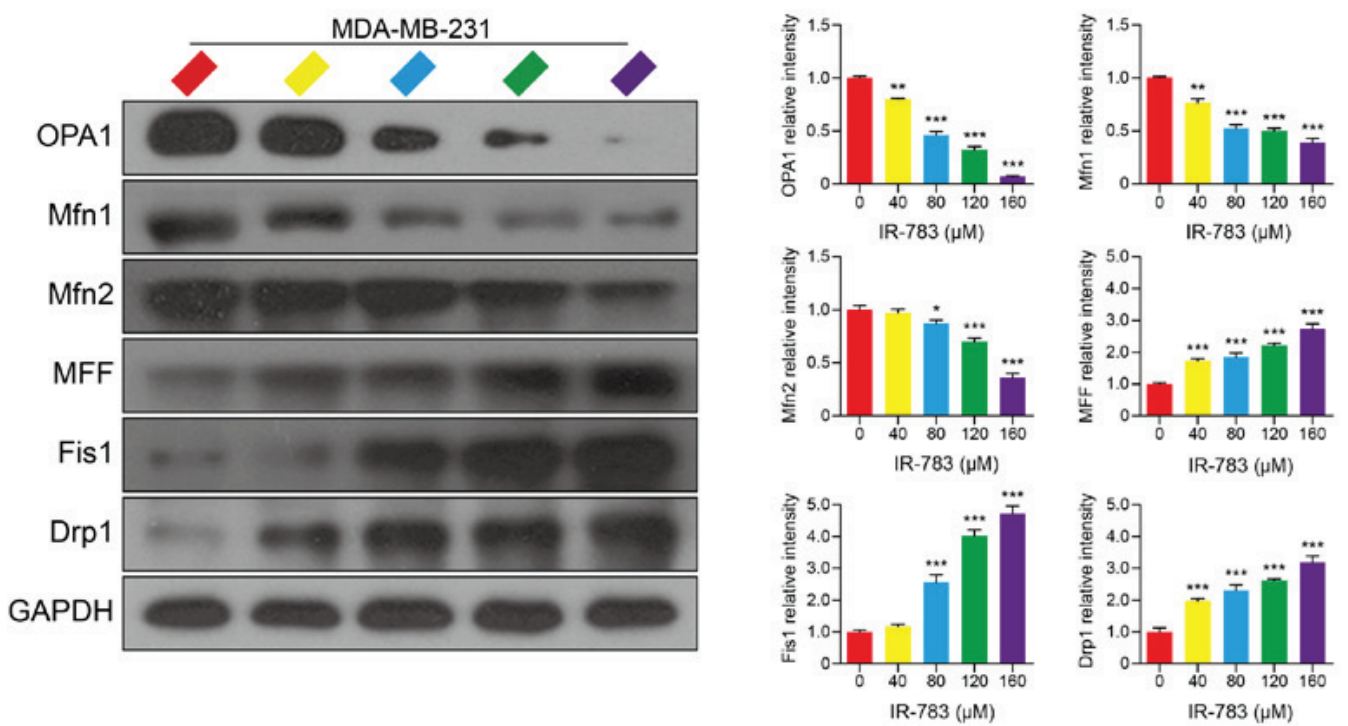

Figure 5. IR-783 induces ATP depletion and mitochondrial fission in MDA-MB-231 and MCF-7 cells. (A) MDA-MB-231 and MCF-7 cells were treated with IR-783 $(0,40,80,120$ and $160 \mu \mathrm{M})$ for $24 \mathrm{~h}$ and the intracellular ATP content was measured by a Luminometer microplate reader. All data are expressed as the mean \pm standard error of the mean, from three independent experiments. ${ }^{*} \mathrm{P}<0.05,{ }^{* * *} \mathrm{P}<0.001$ vs. the MCF-7 control group, ${ }^{\# \# \#} \mathrm{P}<0.001$ vs. the MDA-MB-231 control group. (B) MDA-MB-231 cells were exposed to $80 \mu \mathrm{M}$ IR-783 for $24 \mathrm{~h}$ and mitochondria were imaged with a transmission electron microscope. Scale bar, $2 \mu \mathrm{m}$. (C) MDA-MB-231 and MCF-7 cells were treated with $80 \mu \mathrm{M}$ IR-783 for $24 \mathrm{~h}$, then stained with MitoTracker Red CMXRos (red) and analyzed by a confocal microscope. Scale bar, $20 \mu \mathrm{m}$. (D) Western blotting was performed to assess the expression of OPA1, Mfn1, Mfn2, MFF, Fis1 and Drp1 of MDA-MB-231 cells, and GAPDH was used as the loading control. The relative expression of proteins compared with GAPDH was presented, and was determined with Quantity One software. All data are expressed as the mean \pm standard deviation $(n=3) .{ }^{*} \mathrm{P}<0.05,{ }^{* *} \mathrm{P}<0.01,{ }^{* * * *} \mathrm{P}<0.001$ vs. the control group. Drp1, dynamin-related protein 1; Fis1, mitochondrial fission 1 protein; Mfn, mitofusin; MFF, mitochondrial fission factor; OPA1, optic atrophy 1.

and G2/M phases. Cyclins bind to corresponding CDKs and activate them to regulate the transition of cell cycle phases, which serves a key role in regulation of the cell cycle (34). In the present study, Cyclin D1, Cyclin E and CDK2 were significantly downregulated in MDA-MB-231 cells following IR-783 treatment. These findings suggested that IR-783 induced cell 
cycle arrest at the G0/G1 phase by downregulating Cyclin D1, Cyclin E and CDK2. Direct analysis of DNA synthesis is one of the most accurate ways of assessing cell proliferation. Thus, we performed an EdU assay, an immunochemical method for the detection of the nucleotide analog which is incorporated into replicated DNA (35). We observed that the number of EdU-positive cells was significantly lower in IR-783-treated cells compared with control group cells; These findings indicated that IR-783 inhibited MDA-MB-231 and MCF-7 cell proliferation.

Metastasis remains the cause of $90 \%$ of mortalities from solid tumors (36). The migration and invasive abilities of tumor cells are essential for tumor metastasis. Members of the MMP family are commonly considered as biomakers for cancers. In particular, MMP-2 and MMP-9 are typical members among the MMPs, and are able to degrade type IV collagen, which induces cancer cell metastasis by promoting the primary tumor migration $(37,38)$. In the present study, IR-783 treatment markedly inhibited wound-closure ability of MDA-MB-231 in a wound healing assay and the migration ability of MDA-MB-231 and MCF-7 cells was also suppressed as determined via a Transwell assay. In addition, the expression of MMP-2 and MMP-9 in MDA-MB-231 cells were decreased after IR-783 treatment. On the contrary, previous researchers have revealed that filopodia are associated with cancer cell migration and invasion (39). Furthermore, cancer cell migration can be suppressed by inhibiting filopodia formation ability in vitro (40). F-actin has been reported as a key factor in filopodia, and participated in filopodia extension and retraction at the cell surface. In the present study, IR-783 inhibited MDA-MB-231 and MCF-7 cell filopodia formation, while decreases in polymerized F-actin were detected, indicating that the metastatic ability of MDA-MB-231 and MCF-7 cell was attenuated by IR-783 through inhibiting filopodia formation.

It has been reported that blocking ATP production can inhibit filopodia formation and cell migration (41). We observed that IR-783 treatment inhibited MDA-MB-231 and MCF-7 cell migration and filopodia formation. In addition, we assessed the content of ATP using a microplate reader. The results revealed that IR-783 treatment decreased the levels of ATP in MDA-MB-231 and MCF-7 cells in a dose-dependent manner. ATP depletion has also been reported as an indicator of mitochondrial dysfunction (30). Our results of transmission electron microscopy and immunofluorescence analysis showed that IR-783 treatment led to mitochondrial injury and a notable increase in mitochondrial fission, evidenced by more small, punctate, swelled, cristae disintegrating and vacant mitochondria. Abnormal mitochondrial morphology is attributed to imbalances in mitochondrial fission and fusion $(21,42)$. Numerous proteins and pathways are involved in mitochondrial fusion and fission, while the initial fusion of mitochondria requires the presence of OPA1, Mfn1 and Mfn2 at the inner or outer mitochondrial membrane $(21,43)$. Whereas fission is primarily regulated by the proteins: Drp1, Fis1 and MFF (43). After cells are stimulated under fission-promoting conditions, outer mitochondrial membrane proteins Fis1 and MFF can recruit Drp1 translocation from the cytosol to the mitochondria, and initiate mitochondrial fission (44). Our findings of western blotting demonstrated that IR-783 treatment significantly decreased the expression of the mitochondrial fusion proteins OPA1, Mfn1 and Mfn2, whereas that of the mitochondrial fission proteins Drp1, Fis1 and MFF had increased in MDA-MB-231 cells. Collectively, these results demonstrated that IR-783 inhibited ATP production by inducing mitochondrial fission.

In summary, these data demonstrated that IR-783 inhibited MDA-MB-231 and MCF-7 cell proliferation and migration by inducing mitochondrial fission and subsequently decreasing ATP levels, resulted in cell cycle arrest and filopodia formation inhibition. Our findings could provide a novel mechanistic basis for the application of IR-783 in the treatment of breast cancer.

\section{Acknowledgements}

Not applicable.

\section{Funding}

This work was supported by the National Natural Science Foundation of China (grant nos. 81874357, 81703481 and 81801273), Natural Science Foundation of Chongqing (grant nos. cstc2018jcyjAX0183 and cstc2015jcyjA10011).

\section{Availability of data and materials}

The datasets generated and analyzed during the current study are available from the corresponding author upon reasonable request.

\section{Authors' contributions}

PL, YZ and RZ conceived and designed the study. PL, FS, YL, WL, MZ and QT performed the experiments. FL, JH, $\mathrm{HZ}, \mathrm{CH}$ and WL analyzed the data. PL, YL and YZ wrote the manuscript. GL and QZ reviewed and revised the manuscript. All authors read and approved the manuscript and agreed to be accountable for all aspects of the research in ensuring that the accuracy or integrity of any part of the report work are appropriately investigated and resolved.

\section{Ethics approval and consent to participate}

Not applicable.

\section{Patient consent for publication}

Not applicable.

\section{Competing interests}

The authors declare that they have no competing interests.

\section{References}

1. Dai X, Li T, Bai Z, Yang Y, Liu X, Zhan J and Shi B: Breast cancer intrinsic subtype classification, clinical use and future trends. Am J Cancer Res 5: 2929-2943, 2015.

2. Wang B, Xing Z, Wang F, Yuan X and Zhang Y: Fangchinoline inhibits migration and causes apoptosis of human breast cancer MDA-MB-231 cells. Oncol Lett 14: 5307-5312, 2017. 
3. He MY, Rancoule C, Rehailia-Blanchard A, Espenel S, Trone JC, Bernichon E, Guillaume E, Vallard A and Magné N: Radiotherapy in triple-negative breast cancer: Current situation and upcoming strategies. Crit Rev Oncol Hematol 131: 96-101, 2018.

4. Mathe A, Wong-Brown M, Morten B, Forbes JF, Braye SG, Avery-Kiejda KA and Scott RJ: Novel genes associated with lymph node metastasis in triple negative breast cancer. Sci Rep 5: 15832,2015

5. Jones JE, Busi SB, Mitchem JB, Amos-Landgraf JM and Lewis MR: Evaluation of a tumor-targeting, near-infrared fluorescent peptide for early detection and endoscopic resection of polyps in a rat model of colorectal cancer. Mol Imaging 17: $1536012118790065,2018$.

6. Nagaya T, Okuyama S, Ogata F, Maruoka Y, Choyke PL and Kobayashi H: Endoscopic near infrared photoimmunotherapy using a fiber optic diffuser for peritoneal dissemination of gastric cancer. Cancer Sci 109: 1902-1908, 2018.

7. Yang X, Shao C, Wang R, Chu CY, Hu P, Master V, Osunkoya AO, Kim HL, Zhau HE and Chung LWK: Optical imaging of kidney cancer with novel near infrared heptamethine carbocyanine fluorescent dyes. J Urol 189: 702-710, 2013.

8. Holt D, Okusanya O, Judy R, Venegas O, Jiang J, DeJesus E, Eruslanov E, Quatromoni J, Bhojnagarwala P, Deshpande C, et al: Intraoperative near-infrared imaging can distinguish cancer from normal tissue but not inflammation. PLoS One 9: e103342, 2014.

9. Deng G, Li S, Sun Z, Li W, Zhou L, Zhang J, Gong P and Cai L: Near-infrared fluorescence imaging in the largely unexplored window of 900-1,000 nm. Theranostics 8: 4116-4128, 2018.

10. Wu JB, Shi C, Chu GC, Xu Q, Zhang Y, Li Q, Yu JS, Zhau HE and Chung LW: Near-infrared fluorescence heptamethine carbocyanine dyes mediate imaging and targeted drug delivery for human brain tumor. Biomaterials 67: 1-10, 2015.

11. Shao C, Liao CP, Hu P, Chu CY, Zhang L, Bui MH, Ng CS, Josephson DY, Knudsen B, Tighiouart M, et al: Detection of live circulating tumor cells by a class of near-infrared heptamethine carbocyanine dyes in patients with localized and metastatic prostate cancer. PLoS One 9: e88967, 2014.

12. Cohen S and Margel S; S. C S M: Engineering of near IR fluorescent albumin nanoparticles for in vivo detection of colon cancer. J Nanobiotechnology 10: 36, 2012.

13. Zhang J, Liu Z, Lian P, Qian J, Li X, Wang L, Fu W, Chen L, Wei X and Li C: Selective imaging and cancer cell death via $\mathrm{pH}$ switchable nearinfrared fluorescence and photothermal effects. Chem Sci 7: 5995-6005, 2016

14. Thomas RG and Jeong YY: NIRF heptamethine cyanine dye nanocomplexes for multi modal theranosis of tumors. Chonnam Med J 53: 83-94, 2017.

15. Tang Q, Liu W, Zhang Q, Huang J, Hu C, Liu Y, Wang Q, Zhou M, Lai W, Sheng F, et al: Dynamin-related protein 1-mediated mitochondrial fission contributes to IR-783-induced apoptosis in human breast cancer cells. J Cell Mol Med 22: 4474-4485, 2018.

16. Hou L, Yang X, Ren J, Wang Y, Zhang H, Feng Q, Shi Y, Shan X, Yuan Y and Zhang Z: A novel redox-sensitive system based on single-walled carbon nanotubes for chemo-photothermal therapy and magnetic resonance imaging. Int $\mathbf{J}$ Nanomedicine 11: 607-624, 2016

17. Tokarz P and Blasiak J: Role of mitochondria in carcinogenesis Acta Biochim Pol 61: 671-678, 2014.

18. Eirin A, Lerman A and Lerman LO: Mitochondria: A pathogenic paradigm in hypertensive renal disease. Hypertension 65 : 264-270, 2015

19. Ruan S, Zhang Z, Tian X, Huang D, Liu W, Yang B, Shen M and Tao F: Compound fuling granule suppresses ovarian cancer development and progression by disrupting mitochondrial function, galactose and fatty acid metabolism. J Cancer 9: 3382-3393, 2018

20. Scott I and Youle RJ: Mitochondrial fission and fusion. Essays Biochem 47: 85-98, 2010.

21. Han XJ, Yang ZJ, Jiang LP, Wei YF, Liao MF, Qian Y, Li Y, Huang X, Wang JB, Xin HB, et al: Mitochondrial dynamics regulates hypoxia-induced migration and antineoplastic activity of cisplatin in breast cancer cells. Int J Oncol 46: 691-700, 2015.

22. Matsuishi YI, Kato H, Masuda K, Yamaza H, Hirofuji Y, Sato H, Wada H, Kiyoshima T and Nonaka K: Accelerated dentinogenesis by inhibiting the mitochondrial fission factor, dynamin related protein 1. Biochem Biophys Res Commun 495: 1655-1660, 2018.

23. Archer SL: Mitochondrial dynamics - mitochondrial fission and fusion in human diseases. N Engl J Med 369: 2236-2251, 2013.

24. Westermann B: Mitochondrial fusion and fission in cell life and death. Nat Rev Mol Cell Biol 11: 872-884, 2010
25. Eatemadi A, Aiyelabegan HT, Negahdari B, Mazlomi MA, Daraee H, Daraee N, Eatemadi R and Sadroddiny E: Role of protease and protease inhibitors in cancer pathogenesis and treatment. Biomed Pharmacother 86: 221-231, 2017.

26. Han S, Huang J, Liu B, Xing B, Bordeleau F, Reinhart-King CA, $\mathrm{Li}$ W, Zhang JJ and Huang XY: Improving fascin inhibitors to block tumor cell migration and metastasis. Mol Oncol 10: 966-980, 2016.

27. Shibue T, Brooks MW, Inan MF, Reinhardt F and Weinberg RA: The outgrowth of micrometastases is enabled by the formation of filopodium-like protrusions. Cancer Discov 2: 706-721, 2012

28. Atilgan E, Wirtz D and Sun SX: Mechanics and dynamics of actin-driven thin membrane protrusions. Biophys J 90: 65-76, 2006.

29. Ke R, Xu Q, Li C, Luo L and Huang D: Mechanisms of AMPK in the maintenance of ATP balance during energy metabolism. Cell Biol Int 42: 384-392, 2018.

30. Wang X, Li Y, Qian Y, Cao Y, Shriwas P, Zhang H and Chen X: Extracellular ATP, as an energy and phosphorylating molecule, induces different types of drug resistances in cancer cells through ATP internalization and intracellular ATP level increase. Oncotarget 8: 87860-87877, 2017.

31. Yang X, Shi C, Tong R, Qian W, Zhau HE, Wang R, Zhu G, Cheng J, Yang VW, Cheng T, et al: Near IR heptamethine cyanine dye-mediated cancer imaging. Clin Cancer Res 16: 2833-2844, 2010.

32. Yuan J, Yi X, Yan F, Wang F, Qin W, Wu G, Yang X, Shao C and Chung LW: Near infrared fluorescence imaging of prostate cancer using heptamethine carbocyanine dyes. Mol Med Rep 11: 821-828, 2015.

33. Papaccio F, Paino F, Regad T, Papaccio G, Desiderio V and Tirino V: Concise Review: Cancer cells, cancer stem cells, and mesenchymal stem cells: Influence in cancer development. Stem Cells Transl Med 6: 2115-2125, 2017.

34. Sun L, Huang Y, Wei Q, Tong X, Cai R, Nalepa G and Ye X: Cyclin E-CDK2 protein phosphorylates plant homeodomain finger protein 8 (PHF8) and regulates its function in the cell cycle. J Biol Chem 290: 4075-4085, 2015.

35. Zhang R, Wei YH, Zhao CY, Song HY, Shen N, Cui X, Gao X, Qi ZT, Zhong M and Shen W: EDIL3 depletion suppress epithelial-mesenchymal transition of lens epithelial cells via transforming growth factor $\beta$ pathway. Int J Ophthalmol 11: 18-24, 2018.

36. Gupta GP and Massagué J: Cancer metastasis: Building a framework. Cell 127: 679-695, 2006.

37. Benson CS, Babu SD, Radhakrishna S, Selvamurugan N and Ravi Sankar B: Expression of matrix metalloproteinases in human breast cancer tissues. Dis Markers 34: 395-405, 2013.

38. Mendes O, Kim HT and Stoica G: Expression of MMP2, MMP9 and MMP3 in breast cancer brain metastasis in a rat model. Clin Exp Metastasis 22: 237-246, 2005.

39. Flamini MI, Fu X-D, Sanchez AM, Giretti MS, Garibaldi S, Goglia L, Pisaneschi S, Tosi V, Genazzani AR and Simoncini T: Effects of raloxifene on breast cancer cell migration and invasion through the actin cytoskeleton. J Cell Mol Med 13: 2396-2407, 2009.

40. Li Y, Zhang Z, Zhou X, Li L, Liu Q, Wang Z, Bai X, Zhao Y, Shi H, Zhang X, et al: The oncoprotein HBXIP enhances migration of breast cancer cells through increasing filopodia formation involving MEKK2/ERK1/2/Capn4 signaling. Cancer Lett 355: 288-296, 2014

41. Ozawa S, Ueda S, Imamura H, Mori K, Asanuma K, Yanagita M and Nakagawa T: Glycolysis, but not Mitochondria, responsible for intracellular ATP distribution in cortical area of podocytes. Sci Rep 5: 18575, 2015.

42. Tang D, Kang R, Livesey KM, Kroemer G, Billiar TR, Van Houten B, Zeh HJ III and Lotze MT: High-mobility group box 1 is essential for mitochondrial quality control. Cell Metab 13: 701-711, 2011.

43. Newell C, Shutt TE, Ahn Y, Hittel DS, Khan A, Rho JM and Shearer J: Tissue specific impacts of a ketogenic diet on mitochondrial dynamics in the BTBRT+tf/j mouse. Front Physiol 7: $654,2016$.

44. Kar R, Mishra N, Singha PK, Venkatachalam MA and Saikumar P: Mitochondrial remodeling following fission inhibition by $15 \mathrm{~d}-\mathrm{PGJ} 2$ involves molecular changes in mitochondrial fusion protein OPA1. Biochem Biophys Res Commun 399: $548-554,2010$

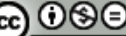

This work is licensed under a Creative Commons Attribution-NonCommercial-NoDerivatives 4.0 International (CC BY-NC-ND 4.0) License. 